\title{
Knowledge about androgenetic alopecia among women and men - a survey research
}

\author{
Wiedza na temat łysienia androgenowego wśród kobiet i mężczyzn - \\ badanie ankietowe
}

\author{
Piotr Rodak, Weronika Dudzik, Kinga Czardobyn-Lotawiec, Maciej Materka, Patryk Zemła, Beata Bergler-Czop \\ Department of Dermatology, Medical University of Silesia, Katowice, Poland
}

Katedra i Klinika Dermatologii, Śląski Uniwersytet Medyczny w Katowicach, Polska

Dermatol Rev/Przegl Dermatol 2021, 108, 317-319

DOI: https://doi.org/10.51 |4/dr.2021.110738

The aim of the research was to assess and compare the knowledge of women and men in various age groups about androgenetic alopecia, its etiopathogenesis and treatment. Androgenetic alopecia (AGA) affects approximately $38 \%$ of patients with alopecia [1]. AGA caused by the action of dihydrotestosterone (DHT) on androgen receptors of hair follicles. DHT is formed from testosterone by 5 a-reductase. This hormone causes regression of the hair follicle and shortening of the anagen phase, leading to hair loss [2]. Hair follicles of the top of the head and the frontal-temporal area are the most sensitive to effects of androgens. This translates into a characteristic pattern of alopecia, intensity of which can be assessed using the Hamilton and Norwood scale [3, 4] in men and Ludwig in women $[4,5]$.

The anonymous questionnaire was answered via the Internet by 553 people, $57.35 \%$ were men. Respondents were divided into six age groups. People aged 19-25 dominated, constituting $67.45 \%$ of the total (fig. 1); 51.54\% lived in cities (over 200,000 inhabitants), a similar number declared secondary education. Results were analyzed statistically. Statistical significance of the correlation was tested with the Fisher test ( $p<0.05$ was considered significant) and their strength - with the Kramer V test. Confidence intervals were set at 95\%. Calculations were performed in IBM SPSS Statistics 26.

Women statistically more often knew the concept of androgenetic alopecia and showed greater interest in the subject than men. They looked for information about AGA more often from doctors, in scientific literature and in cosmetology offices. More than half of respondents knew the physiological daily hair loss and correctly indicated the definition of baldness. In
Celem badania była ocena i porównanie wiedzy kobiet i mężczyzn w różnych grupach wiekowych na temat łysienia androgenowego, jego etiopatogenezy i leczenia. Łysienie androgenowe (androgenetic alopecia - AGA) dotyczy około $38 \%$ pacjentów z łysieniem [1]. Przyczyną AGA jest działanie na receptory androgenowe mieszków włosowych dihydrotestosteronu (DHT), powstającego z testosteronu pod wpływem 5a-reduktazy. Hormon ten powoduje regresje mieszka włosowego i skrócenie fazy anagenu, co prowadzi do wypadania włosów [2]. Największą wrażliwością na działanie androgenów charakteryzują się mieszki włosowe szczytu głowy i okolicy czołowo-skroniowej. Przekłada się to na charakterystyczny wzór łysienia, którego nasilenie można ocenić za pomocą skali Hamiltona i Norwooda [3, 4] u mężczyzn i Ludwiga u kobiet $[4,5]$.

Anonimową ankietę drogą internetową wypełniło 553 osoby, z których 57,35\% stanowili mężczyźni. Badani zostali podzieleni na sześć grup wiekowych, spośród których przeważały osoby w przedziale 19-25 lat, stanowiące $67,45 \%$ ogółu (ryc. 1); 51,54\% mieszkało w miastach powyżej 200 tysięcy mieszkańców, podobna liczba deklarowała wykształcenie średnie. Wyniki poddano analizie statystycznej, gdzie istotność statystyczną korelacji badano testem Fishera ( $p<0,05$ uznano za istotne), a ich siłę - testem $\mathrm{V}$ Kramera. Przedziały ufności określono na poziomie 95\%. Obliczenia przeprowadzono w IBM SPSS Statistics 26.

Kobiety statystycznie częściej stykały się z pojęciem łysienia androgenowego oraz przejawiały większe zainteresowanie tematem niż mężczyźni. Częściej szukały informacji o AGA u lekarzy, w literaturze naukowej i w gabinetach kosmetologicznych. Ponad 


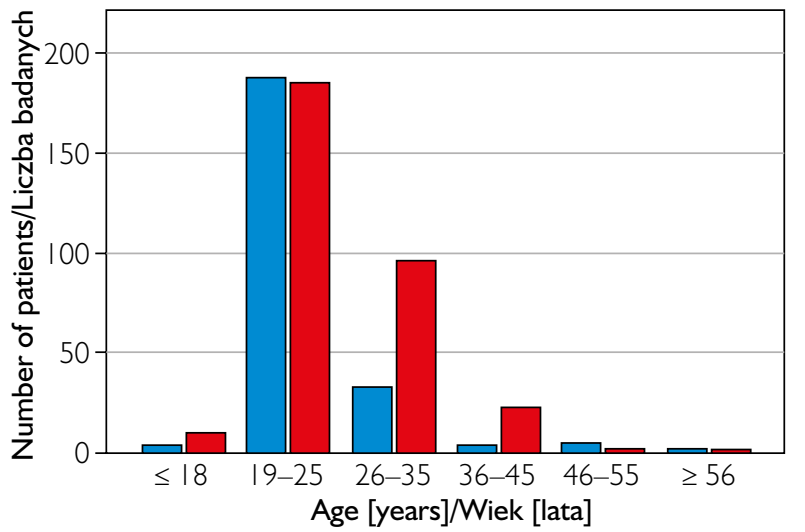

Gender/Płeć

- Female/Kobieta

- Male/Mężczyzna

Figure I. Study group - age

Rycina I. Grupa badana - wiek

both of these questions, a statistically higher percentage of correct answers given by women was noticed. Identification of the etiology of AGA caused major problems, regardless of sex. Only $23.9 \%$ of respondents indicated genetic conditions as the only cause. Respondents often cited excess androgens, stress, medication and comorbidities as reasons for the occurrence of AGA. Determining the AGA phenotype was also problematic. Only $15.9 \%$ of respondents (regardless of sex) indicated the correct combination: thinning of hair at the top of the head and deepening of the frontotemporal angles in men. Men more often claimed that AGA should lead to complete baldness. Moreover, about $20 \%$ of respondents believed that this disease could be manifested by plaque foci of hair loss in various areas of the scalp. In terms of diagnostics, the vast majority of respondents believed that determination of the level of androgens was necessary for the diagnosis. Medical history, supplemented with a trichoscopic examination, was indicated by only $15 \%$ of respondents as sufficient to make the diagnosis, with no significant difference between sexes. $73.1 \%$ of respondents said that AGA required constant therapy. Pharmacological preparations administered topically and orally were indicated as the best and basic methods of treatment. Again, women indicated this option more often. Men, more often than women, were eager to believe in the healing effects of shampoos "on hair loss" and to consider hair transplantation as a form of primary treatment.

No statistically significant relationships between age, place of residence, education, professional activity and marital status, and the answers to questions were noted.

Responses of people with AGA confirmed by a specialist were also compared with responses of healthy people. Patients better identified the cause połowa badanych wiedziała, ile wynosi fizjologiczna dzienna utrata włosów oraz dobrze wskazała definicję łysienia. W obu tych pytaniach statystycznie większy procentowy odsetek poprawnych odpowiedzi był zauważony u kobiet. Duże problemy, niezależnie od płci, sprawiło wskazanie etiologii AGA. Jedynie 23,9\% badanych wskazało uwarunkowania genetyczne jako jedyną przyczynę. Ankietowani często wskazywali na nadmiar androgenów, stres, przyjmowanie leków i choroby towarzyszące jako powody występowania AGA. Problematyczne było też określenie fenotypu AGA. Jedynie 15,9\% ankietowanych (bez względu na płeć) wskazało prawidłową kombinację: przerzedzenia włosów szczytu głowy i pogłębienia kątów czołowo-skroniowych u mężczyzn. Mężczyźni częściej twierdzili, że AGA prowadzi do całkowitego wyłysienia. Ponadto około $20 \%$ ankietowanych uważała, że choroba ta może manifestować się plackowatymi ogniskami utraty włosów w różnych okolicach skóry głowy. W przypadku diagnostyki większość ankietowanych twierdziła, że oznaczenie stężeniu androgenów jest niezbędne do ustalenia rozpoznania. Wywiad, uzupełniony badaniem trichoskopowym, jako wystarczający do postawienia diagnozy wskazało jedynie $15 \%$ ankietowanych, bez istotnej różnicy między płciami. Wśród ankietowanych 73,1\% $\mathrm{z}$ nich twierdziło, że AGA wymaga stałej terapii. Jako najlepszą i podstawową metodę leczenia wskazywali w większości preparaty farmakologiczne podawane miejscowo i doustnie, kobiety częściej wskazywały tę opcję. Mężczyźni, częściej niż kobiety, podawali, że wierzą w lecznicze działanie szamponów „na wypadanie włosów" oraz uznawali przeszczep włosów jako leczenie podstawowe.

Nie zauważono statystycznie istotnego związku między wiekiem, miejscem zamieszkania, wykształceniem, aktywnością zawodową, stanem cywilnym i odpowiedziami na pytania.

Porównane zostały również odpowiedzi osób z potwierdzonym przez specjalistę AGA z odpowiedziami osób zdrowych. Chorzy lepiej identyfikowali przyczynę AGA i lepiej określali morfologie choroby. W pytaniu o diagnozowanie chorzy częściej niż zdrowi wybierali trichoskopię w połączeniu z oznaczaniem stężenia hormonów. W leczeniu podstawowym chorzy częściej niż zdrowi ufali farmakoterapii miejscowej i doustnej.

Kobiety wykazują większe zainteresowanie i ogólną wiedzę na temat fizjologii łysienia oraz epidemiologii i leczenia AGA w porównaniu z mężczyznami. Są one również znacznie bardziej niż mężczyźni skłonne zasięgnąć porady specjalisty w przypadku problemów z włosami. Niezależnie od płci, wiedza o morfologii i diagnostyce AGA jest niewielka. W przypadku leczenia - kobiety bardziej niż mężczyźni skłonne są ufać farmakoterapii. Osoby z po- 
of AGA and better defined the morphology of this disease. When asked about the diagnosis, patients more often than healthy people chose trichoscopy in combination with determination of hormone levels. In basic treatment, patients more often than healthy people trusted topical and oral pharmacotherapy.

Women show more interest and have greater general knowledge about physiology of alopecia and epidemiology and treatment of AGA compared to men. They also, much more likely than men, seek professional advice about hair problems. Regardless of sex, knowledge about morphology and diagnosis of AGA is poor. In terms of treatment, women are more likely to trust pharmacotherapy than men. People with a confirmed diagnosis of AGA have greater knowledge about the disease, its diagnosis and treatment compared to healthy people. twierdzonym rozpoznaniem AGA mają większą wiedzę o chorobie, jej diagnostyce i leczeniu w porównaniu z osobami zdrowymi.

\section{KONFLIKT INTERESÓW}

Autorzy nie zgłaszają konfliktu interesów.

\section{CONFLICT OF INTEREST}

The authors declare no conflict of interest.

\section{References}

\section{Piśmiennictwo}

1. Vañó-Galván S., Saceda-Corralo D., Blume-Peytavi U., Cucchía J., Dlova N.C., Gavazzoni Dias M.F.R., et al.: Frequency of the types of alopecia at twenty-two specialist hair clinics: a multicenter study. Skin Appendage Disord 2019, 5, 309-315.

2. Tai T., Kochhar A.: Physiology and medical treatments for alopecia. Facial Plast Surg Clin North Am 2020, 28, 149-159.

3. Norwood O.T.: Male pattern baldness: classification and incidence. South Med J 1975, 68, 1359-1365.

4. Kozicka K., Lukasik A., Jaworek A., Pastuszczak M., Spałkowska M., Kłosowicz A., et al.: The level of stress and the assessment of selected clinical parameters in patients with androgenetic alopecia. Pol Merkur Lekarski 2020, 48, 427-430.

5. Tas B., Kulacaoglu F., Belli H., Altuntas M.: The tendency towards the development of psychosexual disorders in androgenetic alopecia according to the different stages of hair loss: a cross-sectional study. An Bras Dermatol 2018, 93, 185-190.

Received: 24.11 .2020

Accepted: 5.06 .2021

Otrzymano: $24.11 .2020 \mathrm{r}$.

Zaakceptowano: $5.06 .2021 \mathrm{r}$. 